\title{
Distribution and Taxonomy of High Plant Species in Lake Karakir Bukhara Region
}

\section{Kobilov Aziz Mukhtorovich, Buriev Sulaymon Burievich, Esanov Husniddin Qurbonovich, Yuldoshov Laziz Tolibovich}

Bukhara State University, Bukhara, Uzbekistan

Email: azizqobilov-87@mail.ru

How to cite this paper: Mukhtorovich, K.A., Burievich, B.S., Qurbonovich, E.H. and Tolibovich, Y.L. (2020) Distribution and Taxonomy of High Plant Species in Lake Karakir Bukhara Region. American Journal of Plant Sciences, 11, 589-594. https://doi.org/10.4236/ajps.2020.114044

Received: March 9, 2020

Accepted: April 23, 2020

Published: April 26, 2020

Copyright $\odot 2020$ by author(s) and Scientific Research Publishing Inc. This work is licensed under the Creative Commons Attribution International License (CC BY 4.0).

http://creativecommons.org/licenses/by/4.0/

\begin{abstract}
Lake Karakir (system of lakes) is located in the north west of Bukhara Oasis, it consists of 3 small lakes-a large karakir, a small karakir and an aquarium. The total area of the lake is $26.5-27.2$ thousand hectares. As a result of the research carried out in Lake karakir, 16 families of high water plants, 34 species belonging to 24 categories were identified. The study was carried out mainly on a large spruce and an aquarium. Phragmites australis (Cav.) Trin. ex Steud. (Cav.) Trin. ex Steud. as the dominant species of high water plants, Typha angustifolia L., T. laxmannii Lepech., T. minima Funck. like species are most common.
\end{abstract}

\section{Keywords}

Karakir Lake, Collector-Drainage, Eutrophication, Foodbop, Chlorides, Sulfates, Shallow, Pesticide, Nitrate

\section{Introduction}

The agriculture of Bukhara region is based on irrigation farming and the salinity of its soil is very high. To wash the brine, the fields of the crop are watered in winter. Chlorides dissolved in water, sulfates are washed and removed through Collector-drains. The amount of mineral substances contained in them is $3-5 \mathrm{G}$ in $1 \mathrm{~L}$ of water, in some $10 \mathrm{~g} / \mathrm{l}$. In the composition of collector water, not only nitrate ions, but also pesticides of various poisons are also threeraydi. These substances are added to the Collector waters and collected in lakes in Bukhara region. The waters of the Bukhara region are formed as a result of irrigation and salt washing of crop areas and are collected in such lakes as Dengizkul, Zamombobo, Karakir, Agitma, Devxona, Khadija and Zikri. With the size of the area occupied between these lakes and the number of kidrobions, Lake Karakir occu- 
pies a special place. Lake karakir (system of lakes) is located in the north west of the Bukhara Oasis, it consists of 3 small lakes-a large karakir, a small karakir and an aquarium (Figure 1). Karakir was formed on account of the accumulation of Northern collector waters collected from the Bukhara region. Lake karagör is from closed Lakes, Water does not flow out, the water of the hand is reduced mainly by evaporation. The lake is flooded in $30-40 \mathrm{~m}^{3} / \mathrm{sec}$ in the spring through the northern collector, but there is no possibility of leaving. As a result of the increase in collector water in winter and spring, the area of the lake increases to 26.5 - 27.2 thousand hectares. On account of the high water vapor content in the high-temperature days of summer and a decrease in the water entering the lake by $5-10 \mathrm{~m}^{3} / \mathrm{sec}$, the area of the lake is significantly reduced to 10 - 12 thousand hectares [1] [2]. The object of the study is the high water vegetation of Lake Karakir in Bukhara region.

Data on the study of the Hydrobiology of natural reservoirs located in the territory of Bukhara region are less than threeraydi. And this is due to the fact that the composition of the flora and fauna of the Lakes has not been fully studied. From the location of A. Abdullaev [3] and D.S. Niyozov in the work of [4] it is possible to see malumotlarni about the lakes of Bukhara region and their gidrobiology.

The maximum depth of the lake (large spruce) is 7 - 8 meters, the average depth is $2.0-2.5$ metrs, the minimum is $0.7-1.8$ metrs. The maximum depth of Lake karakır is $5 \%-10 \%$ of its total area, the average depth is $15 \%-20 \%$, the minimum depth is $70 \%-80 \%$. In summer and autumn, the shallow areas of the lake dry up and eutrophication is observed. Plants that fly in the territory of karakir are considered mainly herbaceous plants. The high water plants

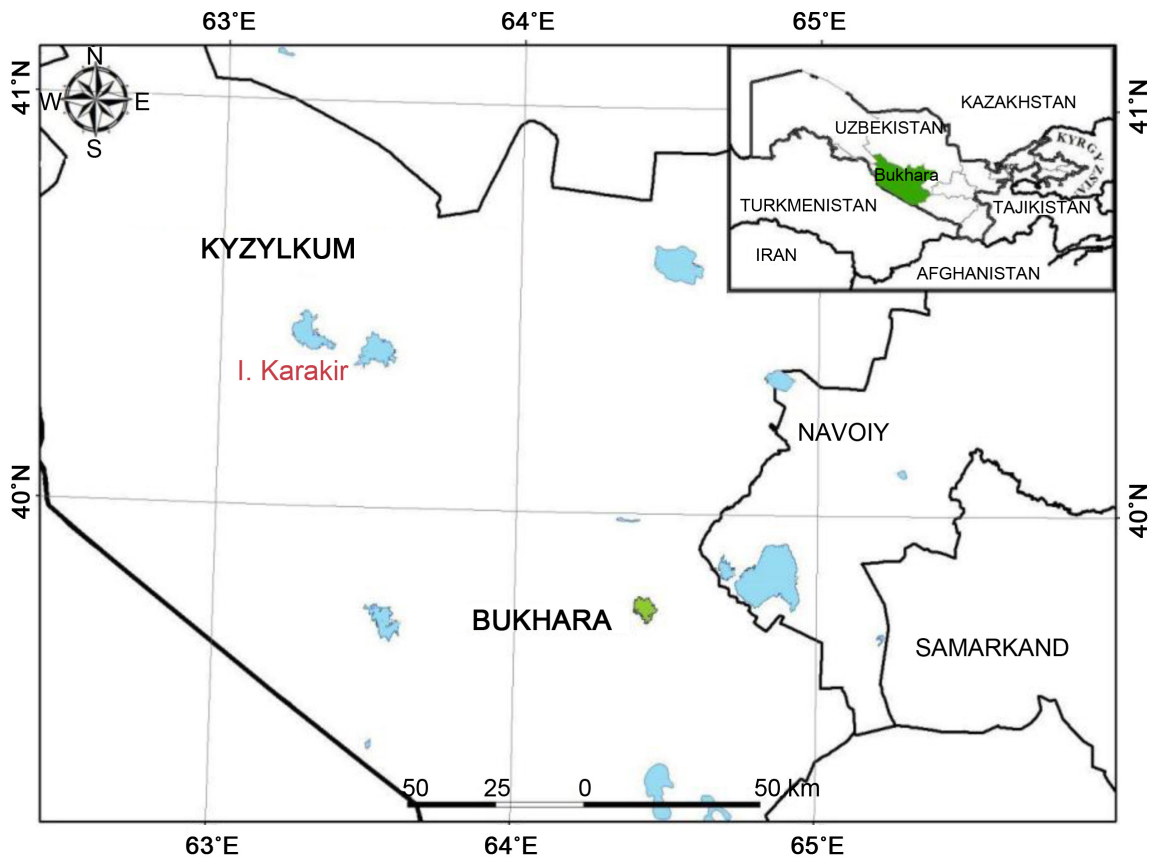

Figure 1. Location of Lake Karakir. 
identified in the lake are three in all waters of Bukhara region. Basically, these plants are present in all collages in the region [5].

\section{Literature Review}

High vegetation of Bukhara region the H.Q. Esanov studied by [6]. It is noted that there are 11 species of high water plants in the water bodies of the region. These species include Ceratophyllum demersum, Batrachium divaricatum, $B$. rionii, Persicaria hydropiper, Myriophyllum spicatum, M. verticillatum, Apium nodiflorum, Veronica anagalloides, Potamogeton crispus, P. perfoliatus, Lemna minor enters. Also the A.R. Kuzmetov, H. Toshov location and others identified 45 species of high water plants belonging to 21 families in Devxona Lake [7]. N. Subkhonov, S. Buriyev conducted research on some high water plants growing in the zovur waters of Bukhara region [8].

\section{Methods of Research}

The data of "Analysis of flora of Bukhara Oasis" [9] were used in the compilation of a list of high plants of Lake karakir. In determining the composition of the species, the method "Flora Uzbekistan", "Opredelitel rasteniy Sredney Azii" [10] and when collecting route herbarium samples [11] were used in collecting herbarium samples. Scientific names of the category and species international indices-International Plants Names Index [12] and authors of taxis Brummit R.K., Powell C.E. [13] was brought on the basis of the manual.

\section{Analysis and Results}

The area of $70 \%-90 \%$ of Lake Karakir is considered to be shallow water, covered with high water vegetation. The high water vegetation of the lake was formed on the account of the northern collector water. As a result of the research carried out on Lake karakir, 16 families of high water plants, 34 species belonging to 24 categories were identified (Table 1). The study was carried out mainly on a large spruce and an aquarium. Phragmites australis (Cav.) Trin. ex Steud. as the dominant species of high water plants, Typha angustifolia L., T. laxmannii Lepech., T. minima Funck. like species are most common. On the shores of the lake, reeds were formed. At $1 \mathrm{~m}^{2}$ level met $150-200$ bush reeds. Phragmites australis (Cav.) Trin. ex Steud. the tubers that grow from the stem of the stem do not allow the development of other plants.

In this lake, various species of high-water plants are distributed. In terms of the number of species being abundant, the Cyperaceae and Poaceae family were the leaders when analyzing the higher plants identified. In the Cyperaceae family there are 3 species belonging to 4 category (Bolchchoenus popovii T.V. Egorova, Scirpus mucronatus L, S. triqueter L., Cyperus rotundus L.) combines. The most common species among these species is the Scorpus L. being representatives of the constellation, they met a lot, mainly in non-deep areas of the lake. The large spruce area is up to $9000 \mathrm{ha}$, and the part of the lake, which remains with the 
Table 1. High water plant composition of Lake Karakir.

\begin{tabular}{lccc}
\hline NO & Families & Genus & Species \\
\hline 1 & Salviniaceae & 1 & 1 \\
2 & Equisetaceae & 1 & 1 \\
3 & Ceratophyllaceae & 1 & 1 \\
4 & Ranunculaceae & 1 & 2 \\
5 & Chenopodiaceae & 2 & 2 \\
6 & Polygonaceae & 1 & 2 \\
7 & Tamaricaceae & 1 & 2 \\
8 & Fabaceae & 1 & 1 \\
9 & Haloragaceae & 1 & 2 \\
10 & Asteraceae & 3 & 3 \\
11 & Juncaceae & 1 & 2 \\
12 & Butomaceae & 1 & 1 \\
13 & Cyperaceae & 3 & 4 \\
14 & Poaceae & 4 & 3 \\
15 & Potamogetonaceae & 1 & 3 \\
16 & Typhaceae & 1 & 4 \\
\hline
\end{tabular}

main water, is located in this area. Despite this, the bottom of the lake is not in the same plane. Even in the middle parts of the lake there are shallow depths of 0.5 - 1.0 meters. In these areas, the Scirpus triqueter (L.) type many threeraydi. In itself, the Poaceae family, which combines 4 categories, 4 species, is also the leader. Identified species $12 \%$ of species belong to this family. Aeluropus litoralis Gouan Parl from family representatives, Erianthus ravennae (L) P. Beauv, Calamagrostis dubia Bunge, Phragmites australis (Cav.) Trin. ex Steud. mainly encountered along the coast.

Phragmites australis (Cav.) Trin. ex Steud. It is the only species that belongs to the category of reeds in Uzbekistan [14] [15]. He is a perennial herbaceous plant. In all water bodies of the Bukhara region, in the aryk, in the waters of the ditch, around the canal, sometimes between the crops are three. Areali is spread throughout the territory of ancient Ortaer. The plant is used as dorivor, fodder, collars, building material, feed.

The constant change in the water in the lake is considered to be favorable conditions for the growing development of these plants, because in the spring the volume of water entering the lake increases, and therefore, on account of this, the volume of Lake Water also increases. Phragmites australis (Cav.) Trin. ex Steud. multiplying through the root feathers out of the water from the shallow parts of the coast for favorable conditions arise. In summer, the lake area is re- 
duced on account of a decrease in water level. Phragmites australis (Cav.) Trin. ex Steud. on the coast most of them will dry out. Constantly covered with water, in places with a depth of $0.5-1.0 \mathrm{~m}$, the Reed grows densely, reaching their height $3.0-4.5 \mathrm{~m}$.

With the variety of series, the Asteraceae family is also distinguished. This family unites in itself 3 category and 3 species. Representative of the Lactuca category Lactuca tatarica (L.) Cam is a low-end flying species on the shores of the lake. Because this species can also be met by many on the shores of the northern collector, which is a water supplier to the lake. Karelinia caspia (Pall.) Less Lake is among the most frequent species around. 3 type of Typhaceae family was identified. This 3 species, which is in the category of Typha, is also one of the most common species. These species are also many threeraydi in the deeper non-parts of the lake. Species such as Typha angustifolia L, T. laxmannii Lepech, T. minima Funck also occupy a large area in the non-deep gills of the lake.

Typha angustifolia L. Perennial rhizome plant. Ditch and effluent waters, threeraydi around the canal. It is used as a food processor, dorivor, forage, fiber plant.

Typha laxmannii Lepech. Perennial rhizome plant. Ditch and effluent waters, threeraydi around the canal. Food processor, dorivor, fodder, fiber plant.

Typha minima Funck. Perennial rhizome plant. Ditch and effluent waters, threeraydi around the canal. Food processor, dorivor, fodder, fiber plant.

3 type of Potamogeton category belonging to the Potamogetonaceae family threeraydi. Potamogeton crispus L, Potamogeton perfoliatus L, Potamogeton heterophyllus Schrebs grow to a depth of $1.5-2.0 \mathrm{~m}$ of the lake due to the fact that they are real aquatic plants. These species are mainly threeraydi in the greater karakir territory. Of the identified families, there are 6 species in 2 Tas, most of which are mainly United into 1 category. For example, Polygonum persicaria L, Polygonum aviculari L species of Polygonum category belonging to the Polygonaceae family were identified. These can be found mainly in the northern collector bays and many in the places where the Collector flows into the lake.

\section{Conclusion}

Lake Karakir is located in the north-west of Bukhara region. The main area of Lake Karakir is covered with high water vegetation. In this area, 34 species of plants belonging to 16 families were identified. Identified plants form a very large biomass during the period of vegetations. Of the high water plants that grow on the lake, they are also used in fishing, in the life of birds, as a quality of nutrient yield for Fur-Bearing Animals and as a building material. It also determines the climate of the lake.

\section{Conflicts of Interest}

The authors declare no conflicts of interest regarding the publication of this paper. 


\section{References}

[1] Buriev, S.B. and Kobilov, A.M. (2019) The Region's Aquatic Vegetation of Lake KaraKira Bukhara. Academicia: An International Multidisciplinary Research Journal, 9, 5-11. https://doi.org/10.5958/2249-7137.2019.00072.7

[2] Mukhtorovich, K.A. and Burievich, B.S. (2019) Distribution of High Water Plants of Lake Karakir in Bukhara Region in Ecological Groups. American Journal of Plant Sciences, 10, 2203-2207. https://doi.org/10.4236/ajps.2019.1012155

[3] Abdullaev, M.A., Niyazov, D.S., Sayfullaev, G.M. and Umarova, Sh. (2003) Ecological Characteristics of the Waste Water of the Bukhara Oasis and the Possibility of Their Use for Fishery Purposes. Ecological Problems in Agriculture. International Science \& Practice Conference, Bukhara, 442-443.

[4] Niyazov, D.S. (2017) Methodical Recommendations for Intensive Fishery in the Aquaculture of Bukhara Oasis Natural Pasture Aquaculture. Bukhara, 36.

[5] Buriev, S.B. and Kobilov, A.M. (2019) Distribution and Taxonomy of High-Water Plant Species in Lake Karakir Bukhara Region. Namangan State University Scientific Bulletin, Наманган, 10, 102-106.

[6] Esanov, H.K. (2016) New Species in the Flora of Bukhara Oasis. Turczaninowia, 19, 77-81. http://turczaninowia.asu.ru https://doi.org/10.14258/turczaninowia.19.2.10

[7] Kuzmetov, A.R., Toshov, H.M., Esanov, H.K. and Isroilov, S.U. (2019) The Species Composition of High-Water Plants and Their Significance in Lake Devkhona, Bukhara Region. Bulletin of the Agricultural Science of Uzbekistan, 2, 138-141.

[8] Subkhonov, N. and Buriev, S. (2009) Description of Some High Water Plants Growing in Zovur Waters of Bukhara Region. Actual Problems of Algology, Mycology and Gidrobotany. International Science Conference, Tashkent, 268-269.

[9] Esanov, H.Q. (2017) Flora Analysis of the Bukhara Oasis. Biol. Science. Philosophy. doc. dis., Tashkent, 179.

[10] (1968-2015) Opredelitel Rasteniy Sredney Azii. V 11-x т. Nayka, Tashkent.

[11] Sccherbakov, A.V. and Mayorov, S.R. (2006) Inventory of Flora and Herbarium Foundations (Methodical Recommendation). Fellowship of Scientific Publications KMK, Moscow, 48.

[12] International Plants Name Index. http://www.ipni.org

[13] Brummit, R.K. and Powell, C.E. (1992) Authors of Plant Names. Royal Botanic Gardens, Kew, 732 p.

[14] Esanov, H.Q., Aslonova, K.A. and Fayzullaev, Sh. (2018) The Importance of High-Water Plants in Reservoirs of the Bukhara Region. Propagation of Microscopic Algae and Higher Aquatic Plants, Their Use in the National Economy. Materials of the Republican Scientific-Practical Conference, Bukhara, 83-86.

[15] Esanov, H.K. and Usmonov, M.X. (2018) Two Alien Species of Asteraceae New to Uzbekistan (Bukhara Oasis). Turczaninowia, 21, 175-180.

http://turczaninowia.asu.ru

https://doi.org/10.14258/turczaninowia.21.4.18 